\title{
Submarine-Based Acoustic Doppler Current Profiler (ADCP) Measurements of the Upper Arctic Ocean
}

\author{
John T. Gunn \\ Earth \& Space Research \\ 1910 Fairview Ave. E. Suite 102 \\ Seattle, WA 98102-3620 \\ phone: (206) 726-0501; fax: (206) 726-0524; email: gunn@esr.org \\ Grant Number: N00014-96-1-0855 \\ http://www.esr.org
}

\section{LONG-TERM GOALS}

The long-term goals of this project are to better understand and quantify the processes that are primarily responsible for redistribution of heat and salt within the Arctic Ocean. The topical focus has been on quantification of the slope-trapped boundary currents and on understanding the roles of small-scale and mesoscale processes in the redistribution of water properties within the central basins. The geographical focus spans the Arctic Basin but emphasizes the Nansen, Amundsen and Makarov basins and the frontal systems that overlie the inter-basin ridges.

\section{OBJECTIVES}

Four primary objectives contribute to the above goals.

- Improve the present understanding of mean circulation patterns in the Arctic, with a focus on the topographically controlled boundary currents that redistribute heat and salt.

- Quantify the speeds, heat, salt and mass transports associated with the boundary currents.

- Improve our understanding of the nature, distribution and dynamics of upper ocean mesoscale eddies and frontal systems, and assess their role in the transport of heat and salt.

- Assess the roles of turbulent mixing and double diffusion in redistributing heat and salt, with an emphasis on the impact of these processes on the halocline and their potential effects on the pack ice cover.

\section{APPROACH}

We approach the above goals through analyses of recently collected field data. The core dataset has been collected from submarine deployments in 1995 through 2000. Data collected from an additional crossbasin transect are expected for 2001 but as yet have not been released. These data span the entire Arctic Ocean and include temperature $(T)$, salinity $(S)$, dissolved oxygen $(D O)$ and upper ocean currents. These data have been supplemented with $T, S$ and current data collected during 1993, 1995 and 1996 cruises of the German research icebreaker Polarstern, with data from the 1994 US/Canadian trans-Arctic section, and with time series data from an array of instrumented moorings that were deployed off the Siberian 


\section{Report Documentation Page}

Public reporting burden for the collection of information is estimated to average 1 hour per response, including the time for reviewing instructions, searching existing data sources, gathering and maintaining the data needed, and completing and reviewing the collection of information Send comments regarding this burden estimate or any other aspect of this collection of information,

including suggestions for reducing this burden, to Washington Headquarters Services, Directorate for Information Operations and Reports, 1215 Jefferson Davis Highway, Suite 1204, Arlington

VA 22202-4302 Respondents should be aware that notwithstanding any other provision of law, no person shall be subject to a penalty for failing to comply with a collection of information if it

does not display a currently valid OMB control number

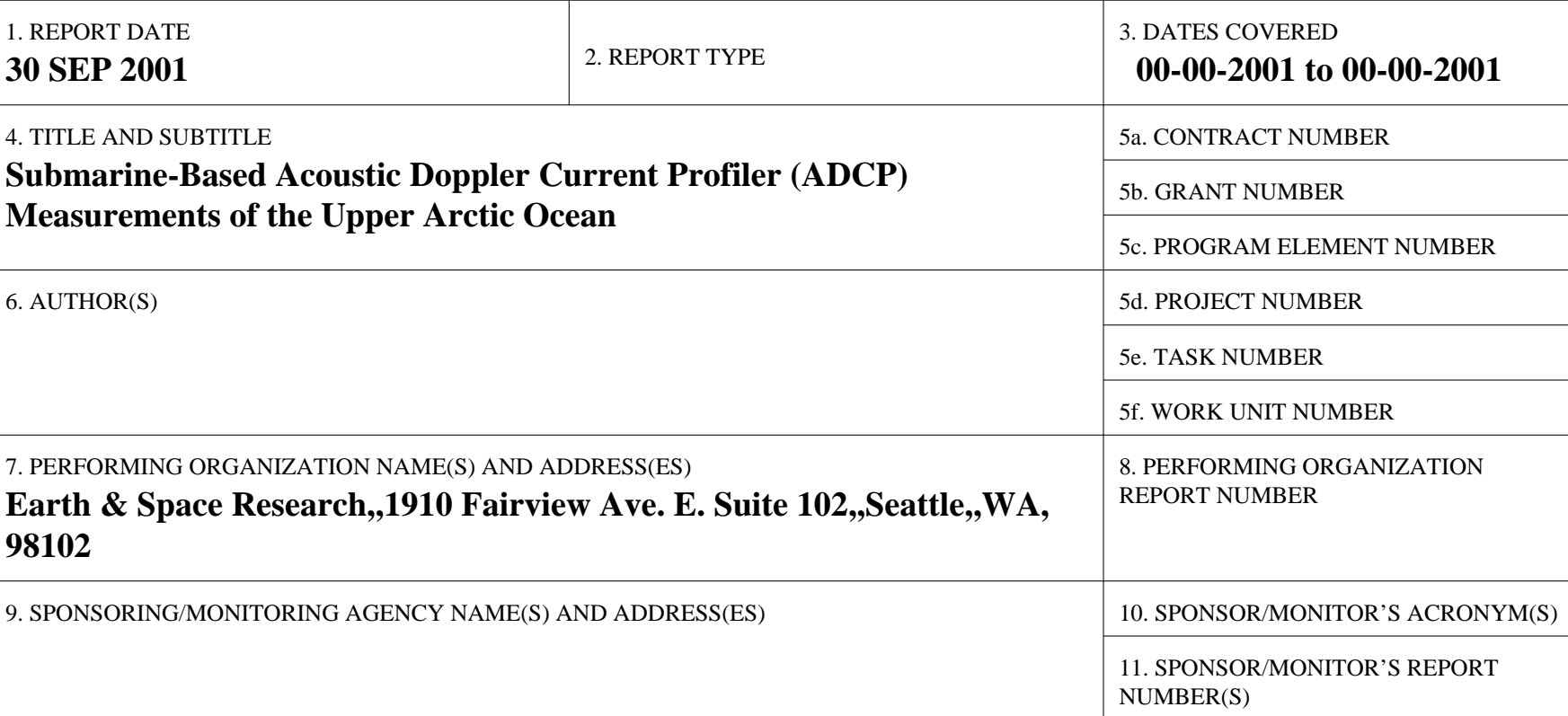

12. DISTRIBUTION/AVAILABILITY STATEMENT

Approved for public release; distribution unlimited

13. SUPPLEMENTARY NOTES

14. ABSTRACT

The long-term goals of this project are to better understand and quantify the processes that are primarily responsible for redistribution of heat and salt within the Arctic Ocean. The topical focus has been on quantification of the slope-trapped boundary currents and on understanding the roles of small-scale and mesoscale processes in the redistribution of water properties within the central basins. The geographical focus spans the Arctic Basin but emphasizes the Nansen, Amundsen and Makarov basins and the frontal systems that overlie the inter-basin ridges.

15. SUBJECT TERMS

16. SECURITY CLASSIFICATION OF:

a REPORT

unclassified b ABSTRACT unclassified c THIS PAGE unclassified
17. LIMITATION OF ABSTRACT

Same as Report (SAR)
18. NUMBER 19a. NAME OF OF PAGES RESPONSIBLE PERSON

6 
continental slope from 1995-1996. Data analysis methods include water mass and time series analyses and intercomparisons among the data and a broad variety of analytical and numerical model results. At present we are focusing on a small number of specific process-related problems while at the same time working toward an integration of the several datasets that should help to provide a holistic view of the Arctic Ocean, its primary circulation and significant internal processes.

\section{WORK COMPLETED}

The ADCP upper ocean current data from the 1998 and 1999 SCICEX programs are being examined in detail to devise a processing strategy that will be less dependent on the position data, which has been the limiting factor in recovering upper ocean current information from this data set. The processing procedures are being verified and we are investigating strategies to arrive at a consistent calibration for the ADCP profile data. The navigation data are also being examined for processing strategies to reduce the noise that interferes with the ADCP calibration.

Progress continues with the data analysis. A meeting in Seattle (December 2000) with R. Anderson, M. Steele, R. Muench and T. Boyd resulted in continued interaction and discussions throughout the year concerning the evolution and apparent partial re-establishment of the Cold Halocline Layer (CHL) during the later part of the 1990's. This effort culminated in the submission of a paper to Geophysical Research Letters in September (Boyd et al, 2001) discussing the partial recovery of the CHL in the Arctic basin. This data set also continues to provide information of the continued evolution of the Atlantic Water layer and upper layer heat flux in the later part of the 1990's and into the year 2000.

The expendable conductivity-temperature-depth (XCTD) data from the 1997 and 1998 SCICEX cruises have been submitted to the National Snow and Ice Data Center for dissemination to interested investigators.

Several items, in various stages of preparation, were completed over the last year and are listed below under Publications.

\section{RESULTS}

Boyd et al (2001) report a partial recovery of the CHL through 1999-2000 with its extent approaching that of the early 1990's. Tracer work carried out using barium derived from Siberian rivers has shown that fluctuations in the CHL over the 1990's was due to large-scale fluctuations in the wind field that impacted in turn the region where shelf water flowed north into the interior Arctic Ocean basin [Guay et al., 2001]. Over the same time period, we reported an extensive warming of the temperature maximum in the Atlantic Water $\left(\mathrm{T}_{\max }\right)$, over the Nansen, Amundsen and Makarov basins (Gunn and Muench, 2001; Woodgate et al., 2001). Extending that analysis with the 2000 SCICEX data (Figure 1) we see notable warming continuing over the Lomonosov and Arctic mid-Ocean (AMOR) ridges. 

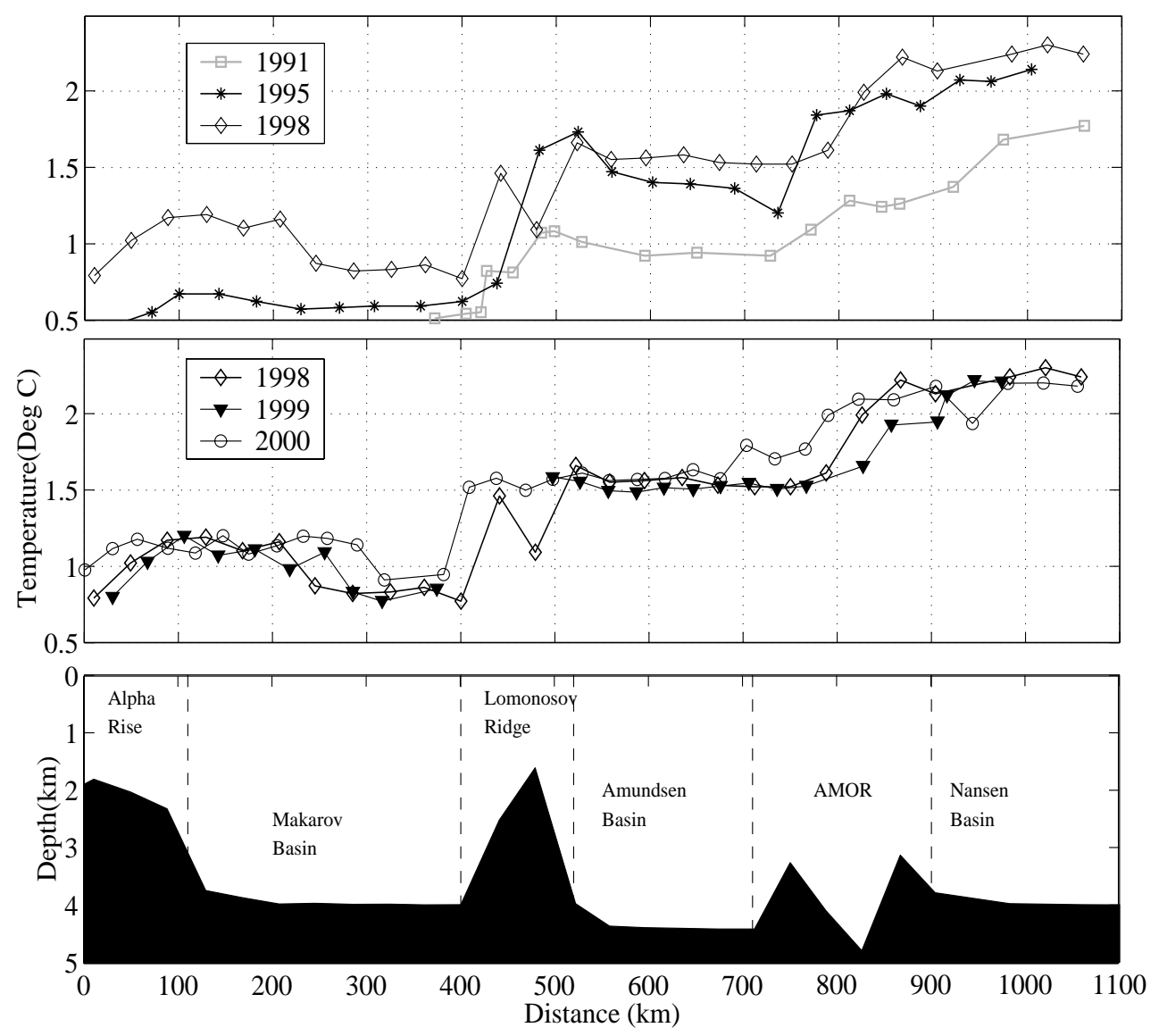

Figure 1. Evolution in time of $T_{\max }$ in the core of the Atlantic Water across the central Arctic Ocean. [Changes in $T_{\max }$ from 1991 -1998 (upper panel) and 1998-2000 (middle panel) as compared to the bathymetry (lower panel)]

In the interior of the basins (Nansen, Amundsen and Makarov) the $\mathrm{T}_{\max }$ was similar to that seen in recent years. The front over the Lomonosov Ridge was displaced towards the Makarov Basin, with some indication of warming compared to 1998 (There was a data gap in 1999, so comparison with that year is inconclusive over the ridge). There is also some warming, $\sim 0.2^{\circ} \mathrm{C}$, (or frontal displacement towards the Amundsen Basin) over the AMOR. There is a slight indication of warming over the Alpha Rise. Because the slope currents in the Arctic Basin follow the ridges, this consistent warming over the different ridges might indicate continued warming of the Atlantic Water core with possible implications for continued positive heat flux into the basins.

\section{IMPACT/APPLICATIONS}

The results concerning Arctic Ocean warming and fluctuations in the CHL have implications, which we are even now trying to understand and quantify, with respect to the diminishing Arctic Ocean pack ice cover. Changes in the ice cover, and related changes in the upper ocean structure, have been recognized as having a potential impact on Naval operations as well as interacting with globally changing climate. 


\section{TRANSITIONS}

None as yet, although information derived from this research contributes to parameterization of climate change models that may ultimately predict changes in the Arctic sea ice cover, an issue of Navy operational concern.

\section{RELATED PROJECTS}

Collaboration continues with other funded programs ("Processing and Analysis of SCICEX-2000 CTD data", T. Boyd, OSU; "Quantifying the Spatial/Temporal Variability of the Arctic Ocean Cold Halocline and Ice/Ocean Interaction" M. Steele, UW/PSC) for comparison of results of upper layer water mass studies and large-scale variability over the Arctic.

Results on upper ocean mixing processes are being directly integrated with results being obtained from the Weddell Sea AnzFlux (Antarctic Zone Fluxes) and international DOVETAIL (Deep Ocean Ventilation Through Antarctic Intermediate Layers) programs. The integrated results will provide information on the relationships among wind-driven surface currents, tidal currents, bottom topography, sea ice cover, upper ocean stratification and mixing processes over a spectrum of parameter values that typify high latitude oceans.

\section{REFERENCES}

Boyd, T., M. Steele, R.D. Muench and J.T. Gunn, Partial recovery of the Arctic Ocean halocline, submitted to Geophys.Res. Lett., Sept. 2001.

Guay, C.K.H., K.K. Falkner, R.D. Muench, M. Mensch and R. Bayer, Wind-driven transport pathways for Eurasian Arctic river discharge. J. Geophys. Res., 106, 11,469-11,480, 2001.

Gunn, J.T. and R.D. Muench, Observed changes in Arctic Ocean temperature structure over the past half decade, Geophys Res. Lett., 28(6), 1035-1038, 2001.

Woodgate, R.A., K. Aagaard, R.D. Muench, J. Gunn, G. Bjork, B. Rudels, A.T. Roach, U. Schauer, The Arctic Ocean Boundary Current along the Eurasian slope and the adjacent Lomonosov Ridge: Water mass properties, transports and transformations from moored instruments. Deep-Sea Res., 48, 1757-1792, 2001.

\section{PUBLICATIONS}

Boyd, T.J., M. Steele, R.D. Muench and J.T. Gunn, Return of the cold halocline layer to the Eurasian Basin of the Arctic Ocean (abstract only, TOS Meeting poster, April 2001, Miami Beach, FL). Oceanography, 14, 1, 2001.

Boyd, T., M. Steele, R.D. Muench and J.T. Gunn, Partial recovery of the Arctic Ocean halocline, submitted to Geophys. Res. Lett. in Sept. 2001.

Guay, C.K.H., K.K. Falkner, R.D. Muench, M. Mensch and R. Bayer, Wind-driven transport pathways for Eurasian Arctic river discharge. J. Geophys. Res., 106, 11,469-11,480, 2001. 
Gunn, J.T. and R.D. Muench, Observed changes in Arctic Ocean temperature structure over the past half decade, Geophys Res. Lett., 28(6), 1035-1038, 2001.

Muench, R.D., J.T. Gunn, T.E. Whitledge, P. Schlosser and W.E. Smethie, Jr., An Arctic Ocean cold core eddy, J. Geophys. Res., 105, 23,997-24,006, 2000.

Rudels, B., R.D. Muench, J. Gunn, U. Schauer, and H.J. Friedrich, Evolution of the Arctic Ocean boundary current north of the Siberian shelves. J. Mar. Systems, 25, 77-99, 2000.

Schauer, U., B. Rudels, E.P. Jones, L.G. Anderson, R.D. Muench, G. Björk, J.H. Swift, V. Ivanov and A.-M. Larsson, Confluence and redistribution of Atlantic water in the Nansen, Amundsen and Makarov basins. Annales Geophysicae, 2001, in press.

Woodgate, R.A., K. Aagaard, R.D. Muench, J. Gunn, G. Björk, B. Rudels, A.T. Roach, U. Schauer, The Arctic Ocean Boundary Current along the Eurasian slope and the adjacent Lomonosov Ridge: Water mass properties, transports and transformations from moored instruments. Deep-Sea Res., 48, 1757-1792, 2001. 